\title{
Antibody Functional Assays as Measures of Fc Receptor-Mediated Immu- nity to HIV - New Technologies and their Impact on the HIV Vaccine Field
}

REVIEW ARTICLE

Bruce D. Wines ${ }^{\mathrm{a}, \mathrm{b}, \mathrm{c}, \# \text {, Hugh Billings }}{ }^{\mathrm{a}, \# \text {, Milla R. Mclean }}{ }^{\mathrm{d}}$, Stephen J. Kent ${ }^{\mathrm{d}, \mathrm{eff}}$ and P. Mark Hogarth ${ }^{\mathrm{a}, \mathrm{b}, \mathrm{c}, *}$

${ }^{a}$ Centre for Biomedical Research, Burnet Institute, Melbourne, Vic 3004, Australia; ${ }^{b}$ Department of Immunology, Monash University Central Clinical School, Melbourne, Victoria 3004, Australia; ${ }^{c}$ Department of Pathology, The University of Melbourne, Victoria, 3010, Australia; ${ }^{d}$ Department of Microbiology and Immunology, Peter Doherty Institute for Infection and Immunity, University of Melbourne, Melbourne, Parkville, Victoria, Australia; ${ }^{e}$ ARC Centre of Excellence in Convergent Bio-Nano Science and Technology, The University of Melbourne, Parkville, Victoria, Australia; ${ }^{f}$ Melbourne Sexual Health Centre, Infectious Diseases Department, Alfred Health, Central Clinical School, Monash University, Victoria, Australia

A R T I C L E H IS T O R Y

Received: December 10, 2016 Revised: February 20, 2017

Accepted: March 09, 2017

DOI:

$10.2174 / 1570162 X 15666170320112247$

Abstract: Background: There is now intense interest in the role of HIV-specific antibodies and the engagement of Fc $\gamma \mathrm{R}$ functions in the control and prevention of HIV infection. The analyses of the RV144 vaccine trial, natural progression cohorts, and macaque models all point to a role for Fc-dependent effector functions, such as cytotoxicity (ADCC) or phagocytosis (ADCP), in the control of HIV. However, reliable assays that can be reproducibly used across different laboratories to measure Fcdependent functions, such as antibody dependent cellular cytotoxicity (ADCC) are limited.

Method: This brief review highlights the importance of Fc properties for immunity to HIV, particularly via Fc $\gamma \mathrm{R}$ diversity and function. We discuss assays used to study FcR mediated functions of HIV-specific Ab, including our recently developed novel cell-free ELISA using homo-dimeric Fc $\gamma \mathrm{R}$ ectodomains to detect functionally relevant viral antigen-specific antibodies.

Results: The binding of these dimeric Fc $\gamma \mathrm{R}$ ectodomains, to closely spaced pairs of $\operatorname{IgG~Fc}$, mimics the engagement and cross-linking of Fc receptors by IgG opsonized virions or infected cells as the essential prerequisite to the induction of Ab-dependent effector functions. The dimeric Fc $\gamma \mathrm{R}$ ELISA reliably correlates with ADCC in patient responses to influenza. The assay is amenable to high throughput and could be standardized across laboratories.

Conclusion: We propose the assay has broader implications for the evaluation of the quality of antibody responses in viral infections and for the rapid evaluation of responses in vaccine development campaigns for HIV and other viral infections.

Keywords: HIV, antibodies, IG, Fc receptors, natural killer cells, ADCC, ADCP, vaccine.

\section{INTRODUCTION}

Fc-gamma receptors $(\mathrm{Fc} \gamma \mathrm{R})$ link the innate and humoral arms of the immune system by engaging IgG antibodies (Ab) and so enabling leukocyte antibody effector functions. Abs bind via their $\mathrm{F}_{\mathrm{ab}}$ region to viral epitopes and their Fc portions bind and cross-link Fc-gamma receptors $(\mathrm{Fc} \gamma \mathrm{R})$ on effector cells such as NK cells, monocytes, macrophages and neutrophils [1-3].

The FcyRs bind IgG but vary in their tissue distribution and expression on innate cells and functional properties. Fc $\gamma$ Rs are key components of both IgG-induced protective inflammatory processes and the regulation of immune responses [1-4]. There is increasing recognition that IgG1 and

\footnotetext{
*Address correspondence to this author at the Centre for Biomedical Research, Burnet Institute, 85 Commercial Road, Melbourne, VIC 3004, Australia; Tel: +61 3 92822255; Fax: +61 3 92822126;

E-mail: mark.hogarth@burnet.edu.au

\#BDW and HB contributed equally.
}

IgG3 interactions with Fc $\gamma$ Rs are important in immune defence against viral infections [2, 5]. Indeed Fc $\gamma$ Rs underlie many effector functions of anti-HIV-1 antibodies, both neutralising antibodies (NAb) and non-neutralising $\mathrm{Ab}$, including ADCC [6], antibody dependent cellular phagocytosis (ADCP), antibody dependent cellular viral inhibition (ADCVI) and antigen presentation [7-10]. While both non-NAbs and NAbs engage Fc $\gamma \mathrm{R}$ mediated effector functions, neutralising antibodies to Env occur relatively late in infection and bNAbs may take years to develop $[11,12]$.

The human and non-human primate (NHP, including macaque) Fc $\gamma$ R family (Fig. 1) consists of several activating receptors (Fc $\gamma$ RI, Fc $\gamma$ RIIa, Fc $\gamma$ RIIIa) and a single inhibitory receptor, Fc $\gamma$ RIIb. Some human leukocytes, such as macrophages, can express all the Fc $\gamma$ Rs: activating Fc $\gamma$ RI, Fc $\gamma$ RIIa, (Fc $\gamma$ RIIc), Fc $\gamma$ RIIIa, and inhibitory Fc $\gamma$ RIIb; thus, the cellular response to IgG-opsonised targets is potentially complex resulting from either the integration of signals from multiple FcRs or the dominance of one receptor signal over the oth- 
ers. Different Fc $\gamma \mathrm{R}$ receptors expressed on different immune cells action different anti-viral immune effector mechanisms [13-17]. Importantly, there is evidence that each activating Fc $\gamma \mathrm{R}$ can contribute to some protective effects of anti-HIV antibodies (e.g. [18-23]). Aggregation of cellular Fc receptors [24], or possibly their reorganisation in the membrane [25] leads to the activation of src family and syk kinases which initiate a cell activation cascade and, depending on the innate cell type, stimulate effector functions such as ADCC and ADCP $[1-3,26]$.

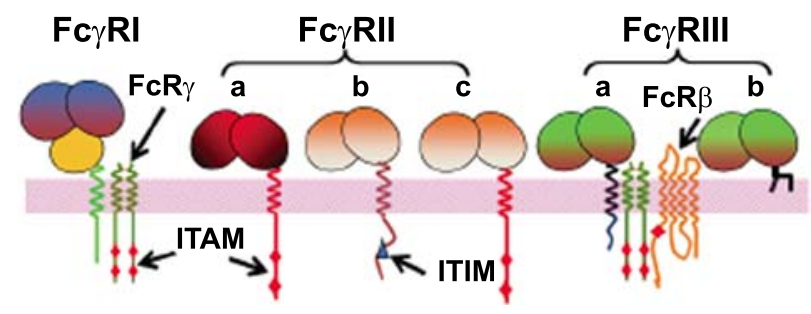

Fig. (1). The human Fc $\gamma R$ family. Fc $\gamma R$ s consist of two or, for Fc $\gamma R$ I, three Ig superfamily domains with the second ectodomain being the principal site for ligand binding. Fc $\gamma$ RIIa contains an ITAM within its cytoplasmic domain, other activating receptors have associated signalling subunits, variously $\mathrm{FcR} \gamma, \mathrm{CD} 3 \zeta$ and FcR $\beta$, that contain the ITAM. Fc $\gamma R I I I b$ has a glycophosphatidylinositol-linked membrane anchor and lacks intrinsic signalling motifs. Fc $\gamma$ RIIb contains a regulatory ITIM motif. Macaques lack Fc $\gamma R I I c$ and Fc $\gamma R$ IIIb.

Further complexity in Fc-function arises from differences in the specificity of human Fc $\gamma$ Rs and their affinities for IgG subclasses $[27,28]$ and can be further affected by genetic polymorphisms of the receptors (Table 1) [26, 29]. FcR categorised as high-affinity bind uncomplexed, monomeric $\mathrm{Ab}$. In the case of FcyRs categorised as lowaffinity, binding of monomeric IgG to cells expressing these receptors is not normally detectable while complexes of $\mathrm{IgG}$ are strongly bound. For the low affinity receptors Fc $\gamma$ RIIa and Fc $\gamma$ RIIIa, reactivity broadly follows the hierarchy $\mathrm{IgG} 3>\operatorname{IgG} 1>>\mathrm{IgG} 2=\mathrm{IgG} 4$, except for the allelic variant of Fc $\gamma$ RIIa with a Histidine at position 131 (H131) which displays strong binding to $\mathrm{IgG} 2$ and has the binding hierarchy, IgG3 > IgG1 IgG2 > IgG4 [1-3, 27]. Thus effective ligand binding by these lower-affinity cellular receptors requires that multiple IgGs are presented in immune complexes or on opsonised targets, such as virally infected cells.

The analysis of antibody responses and evaluation of $\mathrm{mAb}$ in macaques has provided useful insights into possible roles of $\mathrm{Fc} / \mathrm{FcR}$ interactions in resistance to $\mathrm{HIV}$ as described in the following sections. However it should also be noted that despite much similarity there are potentially important differences in diversity, genetics, and biology of antibody and of FcRs in macaques compared to humans which are mentioned below and in [29-33]. Thus, the extrapolation of Fc $\gamma$ R-mediated antibody functions from these models to efficacy in humans should be made with caution. None the less several studies have suggested major roles for the FcRs in effective antibody responses.
2. ANTIBODY FC FUNCTION IN PASSIVE TRANSFER, VACCINE AND NATURAL INFECTION STUDIES.

\subsection{In Vivo Studies I: Macaque and Mouse Models}

A landmark in vivo study in 2007 planted the idea that Fc $\gamma R$-mediated antibody functions will play an important part in HIV therapy. The passive transfer of a bNAb, b12, conferred protection to a SHIV mucosal challenge of macaques, but this protection was substantially reduced when the $\mathrm{bNAb}$ was engineered to reduce Fc $\gamma \mathrm{R}$-dependent effector function [34]. Thus the protective effect of the bNAb was substantially contributed by the Fc $\gamma \mathrm{R}$ binding activity of the antibody. Follow up studies using a more physiological exposure of repeated challenge with low virus doses could be resisted with the Fc $\gamma R$-active form of b12 at a 25 -fold lower concentration than required for $90 \%$ neutralisation [35].

Likewise in macaque vaccination and challenge experiments, IgG effector functions, such as ADCC/ADCP, have been shown to be integral to protection [36] or viremic control [37]. A high-dose SHIV162P3 challenge study showed that immunisation with gp120-CD4 fusion protein (FLSC) elicited titres of CD4i specific Abs [38], in particular coreceptor binding site specific antibodies [39] that correlated with control of viremia. In what is a presumably more physiological repeated low dose challenge of animals vaccinated across varied FLSC/adjuvant regimens, protection from acquisition was correlated with CD4i antibody and ADCC activity, but only in individuals with low CD4 $\mathrm{T}$ cell responses. The negative impact of $\mathrm{T}$ cell activation, reminiscent of human vaccine studies [40], confounded otherwise protective levels of ADCC antibodies [41].

One study aiming to improve vaccine efficacy used an ALVAC-SIV prime with a boost consisting of a gp120-CD4 fusion protein that displays CD4 binding induced epitopes. While this boosting regimen increased antibody responses to the $\mathrm{C} 1$ region and V2 loop, with increased ADCC activity, there was not improved protection against rectal SIV challenge compared to the gp120 boost. In the gp120 boost the V2-peptide antibody response in the mucosa correlated with protection, while for the gp120-CD4 boost serum V2 antibodies correlated with protection [42].

Recently, a human leukocyte reconstituted mouse model was developed to assess antibody mediated protection by neutralisation [43] and activating Fc $\gamma \mathrm{R}$-dependent mechanisms [44]. The full potency of bNAbs in protection and control of viremia has been shown in this model to require Fc $\gamma$ R-dependent extra-neutralising activity [44]. Cocktails of bNAbs can suppress viral rebound in this infection model in an Fc $\gamma R$-dependent manner. In one study, 44 days after treatment with the cocktail of bNAbs, 1 of 21 "humanised" HIV infected mice exhibited viral rebound while a cocktail of bNAbs engineered to lack Fc $\gamma \mathrm{R}$ binding was less effective, with viral rebound occurring in 9 of the 15 infected mice. This model has also proved encouraging in a "cure" experiment showing treatment with inducers of viral transcription that re-activated latent viral reservoirs combined therapeutically with the cocktail of bNAbs to suppress viral rebound in about half the infected mice [45]. 
Table 1. IgG subclass binding profiles*.

\begin{tabular}{|c|c|c|c|c|}
\hline CD64 & Fc $\gamma R I$ & High & $\sim 10^{8}$ & IgG3 $\sim \operatorname{IgG} 1 \geq \operatorname{IgG} 4>>>>\operatorname{IgG} 2$ \\
\hline CD16a & $\begin{array}{l}\text { Fc } \gamma \text { RIIIa }\left(V^{158}\right) \\
\text { Fc } \gamma \text { RIIIa }\left(F^{158}\right)\end{array}$ & $\begin{array}{l}\text { Low } \\
\text { Low }\end{array}$ & $\begin{array}{l}\sim 5 \times 10^{6} \mathrm{M}^{-1} \\
\sim 5 \times 10^{6} \mathrm{M}^{-1}\end{array}$ & $\begin{array}{l}\operatorname{IgG} 3>\operatorname{IgG} 1 \gg>>\operatorname{IgG} 2 \geq \operatorname{IgG} 4 \\
\operatorname{IgG} 3>\operatorname{IgG} 1 \gg>>>\operatorname{IgG} 2 \geq \operatorname{IgG} 4\end{array}$ \\
\hline CD32a & $\begin{array}{l}\text { Fc } \gamma \text { RIIa }\left(\mathrm{H}^{131}\right) \\
\text { Fc } \gamma \text { RIIa }\left(\mathrm{R}^{131}\right)\end{array}$ & $\begin{array}{l}\text { Low } \\
\text { Low }\end{array}$ & $\begin{array}{l}\sim 10^{6} \mathrm{M}^{-1} \\
\sim 10^{6} \mathrm{M}^{-1}\end{array}$ & $\begin{array}{c}\operatorname{IgG} 3>\operatorname{IgG} 1 \approx \operatorname{IgG} 2>>\operatorname{IgG} 4 \\
\operatorname{IgG} 3>\operatorname{IgG} 1>\operatorname{IgG} 2 \approx \operatorname{IgG} 4\end{array}$ \\
\hline $\mathrm{CD} 32 \mathrm{c}$ & Fc $\gamma$ RIIc & Lowest & $\sim 10^{5} \mathrm{M}^{-1}$ & $\operatorname{IgG} 3>\operatorname{IgG} 1 \geq \operatorname{IgG} 4>>\operatorname{IgG} 2$ \\
\hline $\mathrm{CD} 32 \mathrm{~b}$ & Fc $\gamma$ RIIb & Lowest & $\sim 10^{5} \mathrm{M}^{-1}$ & $\operatorname{IgG} 3>\operatorname{IgG} 1 \geq \operatorname{IgG} 4>>\operatorname{IgG} 2$ \\
\hline
\end{tabular}

*For a detailed review of binding specificities and affinities see (Hogarth \& Pietersz, 2012; Wines et al., 2016; Bruhns et al., 2009).

** Note that published affinities can vary but IgG3 is universally the IgG subclass with greatest affinity for any given IgG Fc receptor irrerspective of Affinity Category (Powell et al., 1999, Bruhns et al., 2009).

\subsection{In Vivo Studies II. Human Vaccine and Antibody Trials}

A second pillar of evidence that Fc $\gamma \mathrm{R}$-mediated antibody functions will play an important role in combating HIV comes from the only effective human vaccine trail. The trial, based on ALVAC-HIV Canarypox vector prime containing Env subtype $\mathrm{A} / \mathrm{E}$ and Gag followed by AIDSVAX HIV-1 envelope protein subtype $\mathrm{A} / \mathrm{E}$ and $\mathrm{B}$ boosting vaccines, was conducted on 16,402 individuals in Thailand and produced a $31.2 \%$ protective capacity [46]. While both CTL and antibody responses were induced, both the CTL response and the neutralising antibody responses were relatively weak [47]. Rather than broadly neutralizing antibodies or $\mathrm{CD} 8+\mathrm{T}$ cells, protection in the trial correlated with a profile of $\mathrm{ADCC} / \mathrm{Fc}-$ effector functional antibodies in the absence of an IgA response. [46, 48, 49]. A comparison between the prime-boost RV144 vaccine and previous failed vaccine studies, found the RV144 regimen differed by having the capacity to induce higher levels of IgG antibodies capable of mediating Fc $\gamma \mathrm{R}$ functions, such as ADCC and ADCP [50].

When RV144 and the unsuccessful VAX003 trial were compared, RV144 elicited multi-functional, non-neutralising Abs skewed to higher IgG3 and IgG1 titres, whereas VAX003 elicited monofunctional Abs skewed to IgG4 selection [50]. As IgG3 and IgG1 antibodies have higher affinities for Fc $\gamma$ Rs, this was consistent with a stronger Fc-mediated response being involved in protection in the RV144 trial. Many of the ADCC active antibodies that recognised gp120 could be competed with the archetypical ADCC mAb A32 [51]. Sieve sequence analysis of HIV isolates from infected RV144 participants tested if vaccine responses selectively blocked infection with particular viral genotypes. Vaccine induced V2-Abs bound conformational epitopes and to a linear epitope of V2 residues 169-182 [52] or 165-178 [53]. The sequence of the V2 loop of the transmitted viruses differed from the vaccine Env such that vaccine efficacy reached $48 \%$ against viruses matching the vaccine at lysine$169[52,54]$. This supported the idea that the transmitted breakthrough viruses in vaccinees were selected by ADCC Abs elicited by the vaccine. Since ADCC Abs are relatively easily elicited compared to bNAbs [55-58] and characterised
mAbs such as $\mathrm{CH} 58$ and $\mathrm{CH} 59$ are not extensively hypermutated, the V2 loop is a possible immunogen for developing Fc $\gamma \mathrm{R}$ functional antibody responses [56]. Furthermore the V2 loop has been successfully scaffolded in immunisation studies that elicited ADCP active antibodies in rabbits, whereas immunization with gp120 did not raise ADCP functional Abs [59].

Although unsuccessful overall, the vaccine trial VAX004 showed an inverse correlation between ADCVI activity and risk of infection [60]. Furthermore, an IgG4/2 skewed response negatively impacted on protection [61]. IgG4/2 responses are negative indicators of ADCC and ADCP activity and effector activity is increased following the removal of IgG4 from the Ab pool [50]. ADCC mediated by Natural Killer (NK) cells and ADCP by macrophages and neutrophils have since been further described as important mediators of immunity in the RV144 vaccine response $[48,50,62$, 63].

A recent patient treatment study suggests Fc $\gamma$ Rs may play a role in accelerating the development of anti-HIV bNAbs. In contrast to the slow acquisition of neutralisation capacity in natural infection [11, 64], passive transfer of the bNAb $3 \mathrm{BNC} 117$ to viremic individuals off ART had a vaccine-like effect, stimulating $\mathrm{Ab}$ responses capable of neutralising heterologous tier 2 viruses. Thus, extra to its neutralising activity, the bNAb 3BNC117 directs the humoral immune response, possibly by engaging $\mathrm{Fc}$ receptors on antigen presenting cells [65]. Similar "vaccine-like" effects have been noted with the generation of host anti-tumor immunity following treatment with anti-CD20 Abs. The vaccine effect in this tumor model in Fc $\gamma \mathrm{R}$-humanized mice suggested antigen presentation by the therapeutic $\mathrm{mAb}$ resulted from its formation of immune complexes with its cognate antigen that bound Fc $\gamma$ RIIa on dendritic cells [66]. These studies suggest that Fc-mediated antigen presentation may form a critical feature of optimised HIV vaccines. In addition to its vaccinelike effect, mAb 3BNC117 also cleared infected and ART treated CD4 $\mathrm{T}$ cells adoptively transferred to immunodeficient mice in an Fc $\gamma \mathrm{R}$-dependent manner [67]. Thus this bNAb has multiple Fc $\gamma$ R-dependent anti-viral effects in addition to neutralisation of virus. 


\subsection{In Vivo Studies III: Natural Infection}

The third pillar of evidence for the protective action of HIV-specific Fc $\gamma$ R-activating antibodies has been their association with slowed HIV-1 progression across a range of studies spanning 2 decades [13, 16, 36, 57, 68-70]. Analysis of the rare HIV-1 infected subjects who naturally completely control viral replication (termed "elite controllers") also illustrate the integral role that ADCC and ADCP play in natural immunity. The trend observed in several studies of natural infection was for higher levels of ADCC antibodies and a response skewed to IgG3/1 subclasses in HIV-1 controllers compared to an $\mathrm{IgG} 4 / 2$ subclass skewing in viremic individuals $[18,61,71,72]$. ADCC-antibodies are produced more rapidly following infection than neutralizing antibodies, which typically take months or years to develop [46, 49]. Similar to what was observed in an analysis of the RV144 trial [50] analysis of elite controller antibody responses suggests these patients are not distinguished by a superior activity in a single $\mathrm{Fc}$ functional assay, but rather by activity across a number of different functional assays [61, 73].

Colostral IgG of HIV infected mothers exhibit ADCC activity and are directed against multiple regions of gp120 including CD4i and V1/V2 loop specificities [74]. ADCC functional antibodies have also been associated with protection in maternal-infant passive transfer studies when present in breast milk $[75,76]$.

In sum, although these diverse studies show that in vivo Fc $\gamma$ Rs participate in anti-viral mechanisms of protection, the role of individual receptors requires further elucidation. A brief description of the possible roles of individual Fc $\gamma \mathrm{Rs}$ follows.

\section{Fc $\gamma$ Rs AND HIV-1}

\subsection{FcyRI, the High Affinity FcyR}

Fc $\gamma$ RI (CD64) expression is induced by IFN $\gamma$ under proinflammatory conditions, such as acute HIV infection [77], on monocytes, macrophages, neutrophils, dendritic cells and mast cells [29]. Fc $\gamma$ RI is the high affinity receptor for $\mathrm{IgG}$, binding monomeric IgG and small immune complexes and has a specialised function in the endocytosis [78] and inactivation of toxins [79]. These activities may relate to its activity in ADCVI with anti-HIV polyclonal and monoclonal IgGs [20], wherein the levels of HIV virion opsonisation with IgG may be limiting. Several in vitro studies indicate a particular role for Fc $\gamma \mathrm{RI}$ in patient antibody mediated ADCVI. The inhibitory titre of the anti-gp41 mAbs $2 \mathrm{~F} 5$ or 4E10, was increased up to 300 -fold above neutralisation titre in single round infection studies in monocyte derived macrophages and was dependent on Fc $\gamma$ RI [20]. Subsequent investigation of this Fc $\gamma R I$-dependent inhibition with a panel of mAbs found non-neutralising mAbs specific for the V3 loop or gp41, but not other specificities, were able to inhibit macrophage infection [80]. This enhancing property of Fc $\gamma$ RI was further confirmed when the expression of Fc $\gamma$ RI, but not FcyRIIa or FcyRIIb, in TZM-bl cells conferred greater inhibitory potency on the mAbs $2 \mathrm{~F} 5$ and 4E10 [81]. Fc $\gamma R$ activity, though undefined, was also found to inhibit infection of Langerhans cells and interstitial dendritic cells, early mucosal targets of infection in vivo [82].

Fc $\gamma$ RI has a role in antigen presentation at low concentrations of $\mathrm{IgG}$, as antigen presenting cells from Fc $\gamma$ RI-deficient mice were impaired in stimulating antigen specific CD4 memory $\mathrm{T}$ cell proliferation. However the function of Fc $\gamma$ RI in humoral immunity appears to be regulatory as the end effect on B cell mediated immunity in FcrRI deficient mice was increased $\operatorname{IgG}$ titres to both soluble and cellular antigen [78].

Unlike FcyRII and Fc $\gamma$ RIII, Fc $\gamma$ RI is not polymorphic in humans, however at least 3 variants have been identified in the rhesus macaque $[33,83]$ but the $\operatorname{IgG}$ subclass binding specificity and affinity are near equivalent for the rhesus [33] and pig-tailed macaque [29].

\subsection{FcyRIIa, a Ubiquitous and Polymorphic Receptor}

Fc $\gamma$ RIIa (CD32a) is the most widespread and abundant of the activating IgG receptors, being present on all leukocytes and platelets with the exception of T, B and NK cells [26, 84, 85]. Fc $\gamma$ RIIa is a key FcR in myeloid cell effector responses $[86,87]$. Fc $\gamma$ RIIa expressed on macrophages mediates ADCP of opsonised infected cells and further stimulates the secretion of anti-viral factors such as TNF $\alpha$ and IL-1beta [88].

FcrRIIa genetic polymorphisms are highly relevant to human disease. The High Responder (HR) and low responder (LR) polymorphism at amino acid position 131 [89] is a highly significant risk factor for SLE [90-92], idiopathic thrombocytopenia [93] colitis [94] and rheumatoid arthritis [87, 95, 96], malarial parasitemia levels [97] and aggressive periodontal disease [98]. The protective effect of the H131 polymorphism for severe infection by encapsulated bacteria relates to this receptor being the only human Fc $\gamma \mathrm{R}$ that functionally binds IgG2 [99].

The influence of Fc $\gamma$ RIIa polymorphisms on HIV acquisition or disease progression may be obscured by variations between patient cohorts, differing IgG subclass responses, particularly $\operatorname{IgG} 2$, as well as small patient numbers in some studies. This receptor plays a broad role in immunity, encompassing antigen presenting cell function (e.g. [66]) and Th17 cell development (reviewed in [7]). Two studies have shown an association between the presence of at least one H131 allele and improved outcomes. In one study, homozygosity or heterozygosity for H131 was associated with slower progression to a $\mathrm{CD}^{+}$cell count $<200$ cells $/ \mathrm{mm}^{3}$ [100]. The second study, conducted by French et al. (2010) [19], showed an association between these genotypes and lower HIV replication during interruption of ART following vaccine administration [19]. In this study, patients with IgG2 anti-p24 responses also exhibited lower HIV replication. Although the H131 form of the receptor is associated with marginally increased affinity for IgG1 and IgG3, it is more likely its necessity for IgG2 binding that contributed to improved outcomes in this trial.

However, the former of these two studies also observed that individuals with a homozygous H131 genotype were at greater risk of developing pneumonia as an AIDS-related infection. Conversely, other studies have found no associa- 
tion between this variant and vaccine-induced protection when analysing the RV144 and VAX004 trials [101].

Monocyte Fc $\gamma$ RIIa-dependent phagocytosis has been implicated in the superior activity of antibodies from HIV controllers and untreated chronic progressors in an assay that comprised mixed autologous effectors (monocytes, NK cells) and HIV infected CD4 targets and in an assay of gp120coated bead phagocytosis by the THP1 cell line [18]. Antibodies from HIV infected individuals have increased phagocytic activity over time of infection [102]. A further study using the THP1 monocytic cell line and gp140 coated beads and a methodology that quenched fluorescence of surface bound but not internalised beads, found the RV144 vaccinees lacked antibodies active in phagocytosis.

Fc $\gamma$ RIIa may contribute to protection against acquisition as FcyRIIa on immature dendritic cells is responsible for the enhanced inhibition by anti-Env antibodies of infection of these cells [80]. Furthermore, the optimisation of bNAb VRC01 for binding to FcyRIIa improved phagocytosis by macrophages and neutrophils, two key innate effector types at mucosal sites [103].

FcyRIIa is unique to primates but evaluating antibody function in the macaque is nonetheless not straight forward as ligand binding interactions of this receptor differs in the human and the macaque. The pig-tail [32] and rhesus macaque receptor [33] has lower affinity than the human counterpart and a low activity form (Pro-131) occurs in both macaque species. At least eight variants of Fc $\gamma$ RIIa have been observed in a small cohort of pig-tailed macaque [32] and five in rhesus macaques $[33,83]$.

\subsection{FcyRIIb is a Key Regulator of Ab-Mediated Im- munity}

Fc $\gamma$ RIIb (CD32b) has highly homologous IgG binding ectodomains to those of Fc $\gamma$ RIIa but is an inhibitory receptor. Fc $\gamma$ RIIb regulates cell activation via an ITIM (immunoreceptor tyrosine-based inhibitory motif) within its cytoplasmic domain [104, 105] which recruits SHIP and SHP phosphatases (reviewed in [106]). The Fc $\gamma$ RIIb1 variant controls the activation of B lymphocytes by the BCR via coengagement of the receptor and BCR by antigen:IgG immune complexes. The splice variant, Fc $\gamma$ RIIb2, differs from Fc $\gamma$ RIIb1 by a shorter cytoplasmic domain and is expressed on myeloid cells, although constitutive expression on cells is limited (e.g. basophils, [86]) such that control of activating Fc $\gamma R$ function on myeloid cells by Fc $\gamma$ RIIb2, although potentially potent, is probably cell type and cell state specific [107]. Nonetheless, the Fc $\gamma$ RIIa-dependent phagocytic activity of antibodies of HIV controllers has been reported to be less regulated by Fc $\gamma$ RIIb, and was linked to greater potency of Fc $\gamma$ RIIa-mediated phagocytosis by monocytes and THP1 cells [18]. The molecular basis for HIV controller IgG preferentially binding FcyRIIa over FcyRIIb is not elucidated.

The ratio of $\mathrm{Ab}$ binding by activating ITAM receptors to inhibitory ITIM receptors is an indicator of the net outcome of their activation or regulation of effector cells [108]. Despite the high homology of the of Fc $\gamma$ RIIa and Fc $\gamma$ RIIb ectodomains, human Fc $\gamma$ RIIb has lower affinity than its activa- tory counterpart. However, this is not the case in macaques where the binding affinities of IgG to pig-tailed macaque mnFc $\gamma$ RIIa and mnFc $\gamma$ RIIb are reversed when compared with the human receptors [32]. This higher affinity of macaque Fc $\gamma$ RIIb and lower affinity of the macaque Fc $\gamma$ RIIa raises the possibility of somewhat different regulation of Fc $\gamma$ RIIa by Fc $\gamma$ RIIb in macaque compared to human myeloid cells.

\subsection{Fe $\gamma$ RIIc}

Fc $\gamma$ RIIc (CD32c) is an activating receptor formed by cross over between the $F c \gamma R I I B$ (ectodomain exons) and Fc $\gamma$ RIIA (cytoplasmic domain exons) genes (Fig. 1). Only about $20 \%$ of Caucasians express a functional Fc $\gamma$ RIIc on neutrophils, macrophages and NK cells, and its contribution to antibody function has been little studied [109]. This receptor is not present in the macaque.

An investigation of correlates of protection in the RV144 trial found $F C R 2 C$ genetic polymorphism correlated with vaccine efficacy (up to 91\%) [110]. A recent report by Peng et al. further investigated these correlates finding that these polymorphisms affected expression of Fc $\gamma$ RIIc, Fc $\gamma$ RIIa and also Fc like receptor A (FCRLA) [22]. These results suggest a possible functional association between these polymorphisms and warrants future investigation.

\subsection{FcyRIIIa, a Key Activating Receptor}

FcyRIIIa (CD16a) is expressed on NK cells and phagocytic macrophages. Fc $\gamma$ RIIIa is the most abundant Fc $\gamma R$ on NK cells which are major mediators of ADCC [16] and signals via the signal transduction subunits $\mathrm{FcR} \gamma$ and/or CD3- $\zeta$ [13]. Recent studies of HCMV infection have identified the expansion of adaptive NK cells with altered expression of Syk [111] and down regulation of Fc $\gamma$ RIIIa, but which are more potent ADCC effectors and producers of IFN $\gamma$ [112]. Mechanistically this increased activity has been linked to a switch from Fc $\gamma$ RIIIa association with FcR $\gamma / \mathrm{CD} 3-\zeta$ to CD3- $\zeta$ alone by loss of FcR $\gamma$ expression and synergistic signalling from CD2 which acts as a co-receptor for Fc $\gamma$ RIIIa (reviewed in [113]). This population of "ADCC-specialised" NK cells has also been identified in viremic and cARTtreated HIV infected patients where it is expanded to comprise $90 \%$ of the mature NK compartment [112].

In humans there are two functionally important variants of Fc $\gamma$ RIIIa that have either a valine or phenylalanine at residue 158. These polymorphisms affect the affinity of binding of IgG1 and IgG3. Therapeutic responses to anti-tumour IgG1 mAbs correlated with patient expression of the higher affinity (Val158) allele of Fc $\gamma$ RIIIa, suggesting the importance of the Fc-Fc $\gamma$ RIIIa interaction in the mechanism of action of these antibodies [114, 115]. Consequently, it is well established that this polymorphism enhances $\mathrm{Ab}$ affinity and can be associated with increased ADCC function of these therapeutic mAbs. However, understanding the role of FcyRIIIa in HIV control and protection has proven more difficult (reviewed in [9]). In macaques at least three variants of Fc $\gamma$ RIIIa have been observed [83].

Some studies of Fc $\gamma$ RIIIa polymorphism in HIV pathogenesis, vaccine response, maternal transfer and disease pro- 
gression have yielded associations but overall results have been conflicting. One study looking at Fc $\gamma$ RIIIa alleles in HIV+ patients found that homozygosity for Val158 was associated with a higher rate of disease progression [116]. On the other hand, a large cohort study observed no association between FcrRIII variants and HIV-1 disease progression [100]. A recent study of HIV-1 in Kenyan women also failed to find any association between polymorphisms of either FcyRIIa or Fc $\gamma$ RIIIa and numerous measurements of disease progression [117].

Individuals with low sexual risk-behaviour and V158 homozygosity were correlated with increased infection risk in the VAX004 Trial [101]. Independent analysis of this trial, however found no association between each FcrRII/IIIa variant alone and risk of infection [118]. However, the combination of homozygosity for the lower affinity forms of both FcyRIIIa-FF158 and FcyRIIa-RR131 was associated with higher HIV disease progression in a study by Pandey et al. (2013) [118]. In a study of passive Ab transfer from mother to infant via breast milk, the maternal Fc $\gamma$ RIIIaVal158 allele associated with reduced HIV-1 transmission [119]. It should be noted that the infection context here is different than in post-vaccination sexually transmitted infection.

The conflicting results of studies of FcyRIIIa variants suggest caution in the interpretation of its role in HIV vaccine responses, infection and disease progression. One possible explanation is that although the higher affinity Val158 form may induce heightened NK ADCC efficacy, this could also contribute to increase total immune activation which could be deleterious in HIV acquisition.

\subsection{The Influence of IgG-Fe Glycosylation on FcyR- Mediated Function}

Tumour immunotherapy has driven the development of therapeutic Abs with their Fc glycosylation optimised for interaction with FcyRIIIa and ADCC by NK cells. Analysis of the glycosylation of the $\mathrm{Fc}$ found that the absence of a bisecting fucose in the Asn297-linked carbohydrate greatly increased interaction of the Fc with FcyRIIIa [120-123]. Thus, therapeutic Abs that lack this fucose have been shown to have improved receptor binding and target killing functions $[124,125]$, although mechanisms for improved antitumour outcomes in the clinic are multifactorial [126].

The therapeutic efficacy of a glycan-engineered form of the archetypical anti-HIV bNAb b12 has proved unclear. The nonfucosylated variant of mAb b12 (NFb12), had increased FcyRIIIa binding and 10-fold improved potency in NKmediated ADCC and PBMC-mediated ADCVI assays, but, contrary to expectation, proved in vivo no more potent than wild-type $\mathrm{Ab}$ in protecting SHIV challenged rhesus macaques [127].

It is noteworthy that the enhancement of anti-HIV $\mathrm{mAb}$ b12-Fc binding to Fc $\gamma$ RIIIa has been reported to lower function in assays presumably dependent on different receptors [73]. A similar outcome has been reported previously for the switch away from neutrophil/Fc $\gamma$ RIIa-mediated ADCC to exclusive NK/Fc $\gamma$ RIIIa-mediated ADCC for the Fc $\gamma$ RIIIbinding enhanced anti-tumor mAb Cetuximab. FcyRIIa en- gagement plays a prominent role in neutrophil activation and the FcrRIII-binding enhanced $\mathrm{mAb}$ engaged neutrophil Fc $\gamma$ RIIIb in preference to Fc $\gamma$ RIIa [128]. As already noted neutrophils may be important innate effectors at mucosal sites [103].

Interestingly, IgG antibodies with short glycans, agalactosylated "G0" forms and fucosylated forms in the Fc have recently been found to interact with Mucin-16. This large protein extends $200 \mathrm{~nm}$ above the mucosal epithelial surface and complexes with IgG-Fc. Mucin-16, and possibly other mucins, are thus proposed to improve $\mathrm{Ab}$ specific trapping of antigens in the mucus barrier and extracellular cleavage of crosslinked mucin-16 is likely to shed trapped virus [129]. Some of these glycoforms of Fc interact poorly with Fc $\gamma$ RIIIa (e.g. fucosylated [120-123]) and so are possibly non-inflammatory versions of IgG that may be most appropriate for protection against mucosal challenge, especially considering the lack of evidence for improved protection in SHIV challenge studies by the non-fucosyl-variant of the b12 bNAb [127].

\section{HIV EVASION AND SUBVERSION OF Fe $\gamma$ R- MEDIATED Ab FUNCTIONS}

HIV efficiently evades the host protective antibody response. Envelope sequence diversity, glycosylation and conformational masking of conserved functional sites, together with low levels of Env protein expression on the virion and the infected cell surface all contribute to this evasion [130]. HIV nef and vpu also downregulate CD4 surface expression on infected cells thereby preventing exposure to ADCC antibodies targeting CD4-induced (CD4i) epitopes on Env [131]. HIV not only evades but, recent in vitro studies indicate, HIV also subverts host humoral immunity. This occurs by shed gp120 binding to CD4 on uninfected CD4 T cells which then become opsonised by CD4i specific anti-gp 120 Abs. As such uninfected cells express high CD4 levels, they are efficiently killed by ADCC [132]. Since almost half of anti-HIV antibody specificities may be directed against CD4i (e.g. A32-like Abs, $[39,133])$ this bystander killing by ADCC may comprise a significant component of the loss of CD4 T cells and disease progression.

Indeed a recent ADCC study found the A32 epitope to be poorly expressed on target cells infected with a primary HIV isolate but well expressed and effective for ADCC on targets infected in vitro with a lab adapted HIV strain. It was suggested this difference arises from the unligated Env trimer of the primary strain having stringent conformational integrity that restricted $\mathrm{Ab}$ reactivity to bNAbs, while the lab adapted Env had a 'looser' conformation that exposed a greater range of epitopes including CD4i epitopes [134]. If this proves to be generally true with primary isolates it argues that the CD4i epitope-specific Abs may not contribute to host defence but rather are co-opted by the virus and participate in the decline of CD4 T cells.

This picture is at odds with challenge studies in macaques vaccinated with a gp120-CD4 fusion protein, that efficiently displays the CD4i conformation of gp120. In these studies the CD4i specific Abs elicited are clearly protective (e.g. [41, 42]). Furthermore, a recent microscopy study showed fluorescently labelled virions bound to the 
target cell surface displayed Env epitopes, including CD4i and CD4 binding site epitopes, although this reactivity was lost as entry progressed. It is notable that the level of opsonisation may be modest as 3-6 A32 mAb molecules were estimated to be bound to each cell bound virion [135].

The conformation of the CD4i epitope has been captured in a truncated and stabilised gp120 innerdomain mini-protein which binds A32 and other CD4i specific mAbs [136]. This has been suggested to be a potential vaccine candidate for eliciting CD4i focused antibody responses but will first require an evaluation of the importance of off target killing of uninfected bystander cells to determine if this approach will be effective. Here the multiple effects of small CD4 mimetic compounds, themselves highly potent inhibitors of infection [137], may prove useful for redeeming CD4i ADCC by redirecting it to killing infected targets. First, these act with coreceptor binding site Abs to reveal CD4i epitopes on the unliganded Env to make infected cells ADCC targets [138]. Secondly, they have the benefit of inhibiting shed gp120 binding to uninfected CD4 T cells and so sparing them from possible bystander ADCC killing [132]. Third, they sensitise $\mathrm{HIV}$ for neutralisation such that otherwise ineffective $\mathrm{Ab}$ responses elicited by infection or various immunization regimens, if of sufficient anti-gp120 titre, can effectively neutralise CD4 mimetic treated virus [139]. Recently a small compound has been reported that inhibits Vpu mediated degradation of tetherin, providing a novel approach to sensitising infected cells for ADCC [140]. Together such approaches may play a role in cure strategies involving reactivation of latently infected cells by enhancing Env surface expression and revealing CD4i epitopes in Env, thereby sensitising them to elimination by ADCC [21].

\section{ASSAYS FOR Fe FUNCTION OF ANTI-HIV ANTI- BODIES}

The mere presence of detectable opsonizing $\mathrm{Ab}$ (i.e. without measure of mechanism) may be a poor correlate with protection compared to mechanistic measures of antibody function. Thus ADCC assays are fundamental components of correlates of protection in the evaluation of current and future HIV vaccine efficacy trials. Given the heightened interest in ADCC in vaccine studies and Fc-mediated functions more generally, there is an urgent need for standardized, scalable, rapid and sensitive assays of immunity to HIV. Unfortunately the routinely employed research-based cell culture-based assays to dissect immune correlates of the RV144 trial and of other large HIV research cohorts, although quantitative, are difficult to standardize.

\subsection{What to Measure? Some Considerations in Evalu- ation of Fe Receptor Function}

HIV study outcomes are affected by differing patient populations, infecting viral strains, types of exposure and whether effects in transmission, acquisition or progression are under examination. All these factors affect decisions of how to best evaluate the role of anti-HIV Abs.

As already discussed different IgG subclasses, glycovariants of the Fc, different Fc $\gamma$ Rs, polymorphisms and interspecies differences all influence the functionality of this ligand receptor system. However, as will be explained below, even fully defining the receptor and antibody alleles, subclasses and glycoforms does not sufficiently account for all the factors that modify the Fc receptor function of IgG antibodies. Since only multivalent IgG immune complexes effectively bind to the low affinity Fc receptors, Fc $\gamma$ RII and Fc $\gamma$ RIII, the composition and nature of the complexes formed by IgG opsonisation of antigen, or virion or virus infected cell can profoundly influence receptor activities.

The orientation of Fab binding to an epitope can affect Fc $\gamma \mathrm{R}$ activity. Human antibodies are highly diverse with $\sim 10^{11}$ possible antigen interactions [141] which, in a normal polyvalent immune response, will generate multiple possible ways of binding an epitope. For example the $\mathrm{C} 1$ specific mAbs, N5-i5 and 2.2c, bind to highly related epitopes with similar affinities and yet have a 75 -fold different efficacy in ADCC. Partly this difference results from mAb N5-i5 recognising more cell-CD4 bound Env but, in addition, 2.2c orientates its Fc toward the cell surface, while mAb N5-i5 presents its $\mathrm{Fc}$ away from the target cell. Presumably the latter orientation better engages FcyRIIIa and ADCC function [142].

While a number of studies have examined synergistic effects in antibody binding and virus capture, the density of $\mathrm{IgG}$ opsonisation is a further factor that may influence the efficacy of Fc $\gamma \mathrm{R}$ engagement. Because of the multivalent nature of the interaction of FcRs, combinations of antibodies are likely to be superior over individual mAbs alone for the functional opsonisation of targets with low antigen density. IgG opsonisation is limited by the reduced antigen availability resulting from the combined effects of low Env expression by primary viruses, the gp 120 glycan shield, conformational masking, sequence variation and the downregulation of CD4 and tetherin. Under such circumstances, the simultaneous occupancy of epitopes on Env may markedly affect $\mathrm{F} c \gamma \mathrm{R}$ interactions and the quality of subsequent effector cell responses. Indeed some $\mathrm{V} 2$ and $\mathrm{C} 1$ region specific mAbs elicited in the RV144 trial when paired together showed superior ADCC activity over that of the individual antibodies [143].

The conformational plasticity of Env and the exposure of different epitopes at different points in the virus infectious cycle, as exemplified in the extreme by the differences between bound gp120 and closed Env trimer, result in different forms of Env being optimal for presenting particular epitopes for Ab opsonisation [144-146]. Hence for assays of particular effector functions, whether the Env is native or engineered, in soluble form as monomer or trimer or in the context of a virion or target cell can all affect the outcome of in vitro assays and their potential for correlation with protection in vivo. Further complexity in understanding $\mathrm{Ab} / \mathrm{Fc} \gamma \mathrm{R}$ involvement in anti-HIV immunity arises from the engagement of different $\mathrm{F} c \gamma$ Rs and the varied action of different immune effector cells at different anatomical sites in transmission, acquisition and disease progression.

Presently it is not clear what Fc receptor-dependent function or assay provides the best in vitro correlate to protection or viremic control. Recent studies indicate protection is best indicated by responses that are able to trigger multiple func- 
tions [61]. A comprehensive study of seven Fc $\gamma$ R-dependent functional assays found that different assays, even when assessing ADCC function, were non-redundant and reflected unique aspects of $\mathrm{Ab}$ function. The analysis of multiple ADCC assays in combination best discriminated different patient and vaccinee groups [73].

\subsection{Cell Based Functional Assays for FcR Activating Antibodies}

Most current cell-based assays of Fc $\gamma \mathrm{R}$ function of antibodies focus on NK cells, although as discussed other innate leukocytes can be potent effectors, and typically measure the expression of activation markers, the release of cytokines and lytic proteins or the killing capacity of NK cells and use flow-cytometry or ELISpot techniques [147-149]. Such assays include the rapid-fluorimetric ADCC assay (RFADCC) [150, 151], NK viral inhibition assays [68, 152], lactate dehydrogenase release assay [153], granzyme delivery assays $[154,155]$, and NK cell activation assays measuring interferon-gamma and/or CD107a [13]. Such assays can be long, complex and difficult to standardize or reproduce precisely. Most assays involving donor cells need large amounts of human donor blood as a source of effector cells. There are substantial Fc-receptor polymorphisms across human donors that influence the readouts of these assays adding to issues around variability, standardization and reproducibility across laboratories.

Many assays measure HIV-infected, or gp120-coated, target CD4 T cell killing. Target cells may also be sensitised using inactivated virus [38]. Standard natural cytotoxicity assays assays measure the release of chromium, ${ }^{51} \mathrm{Cr}$, from isotope-labelled unosponised target cells in the presence of NK cells. ADCC is measured by the additional killing of targets in the presence of target specific Abs. This assay was used by Baum et al. (1996) to show that high titres of Abs that mediate ADCC correlated with a slower AIDS progression [69]. Cytotoxicity assays measuring release of europium label from lysed target cells using time resolved fluorescence are replacing the radioisotope label assays [156].

The lactate dehydrogenase (LDH) release cytotoxicity assay, marketed as the CytoTox 96 nonradioactive cytotoxicity assay kit (Promega), is a colorimetric alternative to chromium release assays. The assay measures LDH released upon cell lysis and has been used, for example, in recent studies examining the potential of HIV-1 specific ADCC in killing latently infected cells upon viral reactivation [21] [157].

Granzyme B $(\mathrm{GrB})$ is a serine protease that, on delivery by NK cells into the cytoplasm of target cells, initiates apoptotic signalling and cell death in the target. Upon delivery, the enzyme recognises and cleaves a short peptide sequence in procaspases, activating them and so triggering the apoptotic pathway. The GrB assay, marketed by OncoImmunin as GranToxiLux ${ }^{\circledR}$, measures delivery of the enzyme to target cells, which are preloaded with a GrB targeted substrate that becomes fluorescent upon cleavage. This method was evaluated by Pollara et al. (2011) for measuring the ADCCmediating capacity of Abs against HIV and SIV in humans and non-human primate models [154].
Caspase-3 is an enzyme activated downstream of $\mathrm{GrB}$ and is a key player in the apoptotic process. A second OncoImmunin assay, PanToxiLux ${ }^{\mathrm{TM}}$ measures both GrB and caspase activity. A comparison of the GranToxiLux ${ }^{\circledR}$ and PanToxiLux ${ }^{\mathrm{TM}}$ assays by Konstantinus et al. (2016) found that both were both suitable for measuring NK killing and HIV-specific ADCC activity, although the GranToxilux ${ }^{\circledR}$ assay had improved detection of HIV-Specific NK cell mediated ADCC activity [155]. A T lymphoblastoid cell line, CEM.NK ${ }^{\mathrm{R}}$ CCR5, that is resistant to natural cytotoxicity of NK cells and expresses both CCR5 and endogenous CXCR4 [158] has been the basis of many assays for HIV replication, neutralisation and ADCC.

The Rapid Fluorometric ADCC (RFADCC) assay developed by Gomez-Roman et al. (2005) involves the dual labelling of target cells (e.g. CEM.NK ${ }^{\mathrm{R}}$ CCR5) with the cell membrane marker $\mathrm{PKH}-26$ and a cytoplasmic marker (e.g. CFSE) with the former stain marking targets and the loss of the later stain indicating target killing. This assay has been used to demonstrate that ADCC activity of anti-gp120 Abs elicited in macaques by vaccination correlated with reduced viremia following in vivo SHIV mucosal challenge [37, 150]. Further evaluation of this assay found that monocytes were in fact the main effector cell in PBMCs and trogocytosis occurred with target cell membrane being incorporated into the monocytes [159]. The RFADCC assay has also been used to evaluate RV144 vaccine induced ADCC antibodies showing immune selection of viruses by these Abs [160]. In a modification of RFADCC approach EGFP was expressed in the CEM-NK ${ }^{\mathrm{R}}$ cell line with dual staining by propidium iodide marking killed target cells [161].

Another format of ADCC assay uses CEM.NKR cells expressing high levels of CCR5 that were transduced with a Tat stimulated HIV promoter driving luciferase expression. Killing of the infected CCR5-sLTR-Luc cells is measured by loss of luciferase activity which is specific for infected targets [162]. In another assay, target cells are labelled with a viable cell stain (Far Red DDAO cell tracker, Life technologies), infected with virus, ADCC performed and killed infected targets enumerated by flow cytometry as intracellular stained gag-positive and cell tracker dye-negative. The same study used an infected target specific assay where CEMNKR cells were infected with recombinant virus incorporating IRES-GFP. ADCC was performed in the presence of the fluorescent nuclear stain DAPI, Abs and effector cells with the lysed targets GFP+ and becoming DAPI+ as visualised by live imaging. This demonstrated bNAbs did not cause uninfected bystander killing [11].

Rather than measuring target killing, NK activation assays can be used as a surrogate for ADCC activity. They involve the quantification by flow cytometry of cytokines or markers produced as a result of NK activation. Chung et al. (2009) used this technique to measure the expression of intracellular IFN $\gamma$ and surface CD107a on NK lymphocytes but found poor correlation between IFN $\gamma$-expression and killing in the RFADCC assay [13].

A commercial (Promega) assay for activation of Fc $\gamma$ RIIIa as a surrogate for ADCC uses a Jurkat T cell line expressing a NFAT binding promoter controlling luciferase expression. This assay was used to demonstrate $\mathrm{Vpu}$ regulation of 
tetherin expression inhibits ADCC of infected target cells [163] and that, in macaques persistently infected with an attenuated SIV, acquisition of protective immunity correlated with ADCC activity [55].

Following infection of target cells at low m.o.i., ADCVI assays measure the decrease in viral replication (e.g. levels of p24) in the presence of anti-HIV antibodies and effector cells. Forthal et al. (2001) found plasma from acutely infected patients and normal NK effector cells were able to inhibit viral replication, suggesting a role for antibody and NK cells in early control of infection [68]. The assay can use NK cells or monocytes for killing of infected targets [18]. Other formats measured Fc-dependent direct inhibition of replication in primary macrophages [20].

Ab-dependent phagocytosis assays can use either opsonsised virions, beads or target cells. Phagocytosis of large targets requires actin re-organisation. Although described as phagocytosis $\mathrm{Ab}$ dependent uptake of opsonised virus is more accurately described as endocytosis. For example, the phagocytosis (or endocytosis) of FITC labelled SIV was found to be equivalent when the SIV was opsonised by IgG elicited by either gp120 or CD4-gp120 boost vaccination regimens [42]. Conventional and imaging flow cytometry has shown a hierarchy of IgG3 $>\operatorname{IgG} 1>\operatorname{IgA}$ for the internalisation of fluorescent virus by monocytes [164]. Assays can use distinct labels to distinguish internalised from surface bound opsonised virus or beads. In one such study HIV infection was found to elicit a humoral response able to mediate THP-1 cell phagocytosis of gp140 coated beads, in contrast with the RV144 vaccine response which was inactive [102].

In the absence of knowing the most appropriate effector function on which to focus, a general measure of Fc $\gamma \mathrm{R}$ activating capacity has clear utility.

\subsection{FcyR Binding Assays}

BIAcore assays (e.g. [27, 28]) have been used to survey the binding activities of the different Fc $\gamma$ Rs with IgG subclasses in 1:1 stoichiometric interactions. The normal ligands for cellular Fc $\gamma R$ interactions are complexes of IgG and increased complex size increases the avidity of interaction and binding activity [165]. Therefore more functional antigenspecific assays measure binding of complexes to immobilised recombinant soluble receptors $[18,166]$. For example, recombinant soluble Fc $\gamma \mathrm{R}$ ectodomains with c-terminal hexahistidine tags have been immobilised on plates via antihexahistidine $\mathrm{mAb}$ [166] or nickel [18] to produce an array of receptors for binding IgG ligands. A powerful high through-put assay used receptor coupled beads with antibody binding detected using PE-conjugated anti-human IgG [167]. While these assays give valuable information about immune complex:Fc $\gamma \mathrm{R}$ binding, the stoichiometries of the interactions are not well defined. Another high through-put bead format is an 'alpha screen' competitive binding assay (Perkin Elmer) which has been used to evaluate the affinities of mutant IgGs for Fc $\gamma$ R.

\subsection{Dimeric rsFe $\gamma R$ Assays}

We developed a simple, rapid and scalable biochemical approach to evaluating Fc $\gamma \mathrm{R}$-dependent antibody efficacy in innate effector activation. The assay exploits the intrinsic low affinity interactions of Fc $\gamma$ RII and Fc $\gamma$ RIII by using the avid binding of recombinant ectodomain homodimers Fig. (2). The low affinity Fc receptors, Fc $\gamma$ RII and Fc $\gamma$ RIII, have $10^{-6}$ to $10^{-7} \mathrm{M}^{-1}$ affinities for uncomplexed monomeric IgG1 and functionally bind $\mathrm{IgG}$ opsonised targets and antigens by virtue of the avidity of multiple Fc regions of $\mathrm{IgG}$ opsonised targets binding receptors arrayed on the effector cell surface. Clustering of these receptors leads to their phosphorylation and thereby innate cell activation, and effector function.

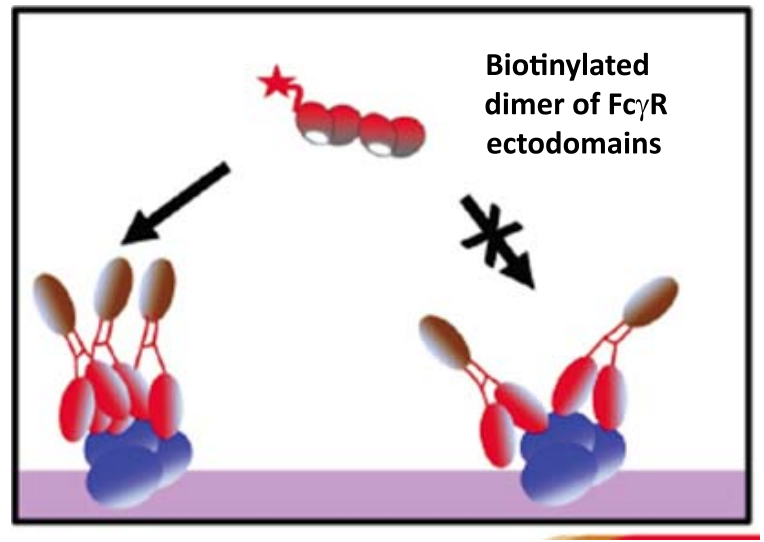

Fig. (2). Left: The dimeric $r s F c \gamma R$ selectively binds pairs of $\mathrm{IgG}$ antibodies bound to neighbouring epitopes and orientated so the Fc regions can be bridged by the two binding units of the dimer. Right: The dimeric $\mathrm{rsF} \gamma \mathrm{R}$ cannot stably bind to IgG immune complexes where the Fc regions are presented too far apart to be bridged by the receptor dimer.

The rationale of our approach to evaluating antibody responses was to exploit the fundamental multivalent aspect of Fc receptor function whereby avid interactions underlies binding, cell activation and ultimately effector function. As the minimal unit of an avid interaction is a dimer we constructed homodimers of the ectodomains of the low affinity Fc $\gamma$ Rs, Fc $\gamma$ RII and Fc $\gamma$ RIII that were linked by their respective membrane proximimal stalks as single polypeptides. Since the stalk regions of the cellular receptors allow some freedom of movement of the ectodomains we reasoned this to be a suitable constraint by which to tether the ligand binding portions of the dimer. As the monomeric ectodomain of the receptors do not bind stably, the observed binding of the dimeric $\mathrm{rsFc} \gamma \mathrm{R}$ ectodomains can be simply interpreted as two IgG antibodies being presented with their Fc regions sufficiently close to be bridged by both ligand binding modules of the engineered dimeric rsFc $\gamma \mathrm{R}$ [168]. Thus, while affected by the quantity of bound IgG, as might be measured with a polyclonal anti-IgG, the binding of dimeric $\mathrm{rsFc} \gamma \mathrm{R}$ to IgG opsonised antigens indicates the favourable proximity/orientation of Fcs. Examination of pooled antibody responses to $\mathrm{H} 1 \mathrm{~N} 1$ hemagglutinin with dimeric rsFc $\gamma$ RIIIa found increased reactivity with IgGs produced subsequent to the H1N1 pandemic, suggesting a greater occupancy of strain specific epitopes upon HA opsonisation with these IgGs. Furthermore, anti-HA antibody activity in the dimeric rsFc $\gamma$ RIIIa assay correlated with NK activation. Studies with HIV infected patients using the assay have found indication of superior dimeric Fc $\gamma \mathrm{R}$ binding activity in elite controller 
sera and conversely diminished activity in Env specific antibodies from cART patients (Vijaya Madhavi, unpublished results). This high-throughput dimeric $\mathrm{rsF} c \gamma \mathrm{R}$ binding ELISA format could find substantial utility in the rapid evaluation of large numbers of HIV vaccine trial samples.

\section{CONCLUSION}

Ample in vivo data show $\mathrm{Fc}$ receptor-mediated functions of anti-HIV IgG play an important, though partially effective, role in natural and vaccine-induced immunity. Optimised Fc functionality will comprise some part of the mix that achieves an HIV cure. The predictive value of in vitro tests for correlating with in vivo protection will improve with future matching of appropriate $\mathrm{Fc}$ receptors, cell types, antibody forms and functional readouts to in vivo protective functions. While NK cell/Fc $\gamma$ RIIIa-mediated ADCC will remain a staple for evaluation of antibody immunity, particularly for control of viremia, other assays, e.g. focused on antibody function in the mucosa, may be more predictive of protection against acquisition. The assay described herein is, to our knowledge, the first attempt to develop a simple in vitro $\mathrm{Fc} \gamma \mathrm{R}$ assay that, in addition to retaining all the $\mathrm{Fc} \gamma \mathrm{R}$ intrinsic properties, such as $\mathrm{IgG}$ subclass and glycoform binding selectivity, is sensitive to the nature of the complex formed between antigen and antibody. Key features of this are the density of IgG occupation of adjacent epitopes and the orientation of the $\mathrm{Fc}$ regions. The ease of this dimeric Fc $\gamma \mathrm{R}$ ELISA assay lends itself as a useful, highthroughput screening method for Fc-mediating antibodies in future HIV vaccine trials and studies of HIV-1 immunity.

\section{LIST OF ABBREVIATIONS}

ADCC = Antibody dependent cellular cytotoxicity

$\mathrm{ADCP}=$ Antibody dependent cellular phagocytosis

ADCVI = Antibody dependent cellular virus inhibition, bNAb, broadly neutralizing antibody

$\mathrm{FcR}=\mathrm{Fc}$ receptor

$\mathrm{rsFcR}=$ Recombinant soluble FcR

\section{CONFLICT OF INTEREST}

This work was funded by Australian National Health and Medical Research Council awards and the Victorian Operational Infrastructure Scheme. The authors declare no conflict of interest.

\section{ACKNOWLEDGEMENTS}

The authors thank Alicia Chenoweth for reading the manuscript.

\section{REFERENCES}

[1] Hogarth PM, Pietersz GA. Fc receptor-targeted therapies for the treatment of inflammation, cancer and beyond. Nat Rev Drug Discovery 2012; 11(4): 311-31.

[2] Nimmerjahn F, Ravetch JV. Divergent Immunoglobulin G subclass activity through selective Fc receptor binding. Science 2005; 310(5753): 1510-2.

[3] Ravetch JV, Bolland S. IgG Fc receptors. Annu Rev Immunol 2001; 19: 275-90.
[4] Nimmerjahn F, Ravetch JV. Fcgamma receptors as regulators of immune responses. Nat Rev Immunol 2008; 8(1): 34-47.

[5] Irani V, Guy AJ, Andrew D, et al. Molecular properties of human IgG subclasses and their implications for designing therapeutic monoclonal antibodies against infectious diseases. Mol Immunol 2015; 67(2 Pt A): 171-82.

[6] Pollara J, Bonsignori M, Moody MA, et al. Epitope specificity of human immunodeficiency virus-1 antibody dependent cellular cytotoxicity [ADCC] responses. Curr HIV Res 2013; 11(5): 37887.

[7] Boesch AW, Brown EP, Ackerman ME. The role of Fc receptors in HIV prevention and therapy. Immunol Rev 2015; 268(1): 296-310.

[8] Caskey M, Klein F, Nussenzweig MC. Broadly neutralizing antibodies for HIV-1 prevention or immunotherapy. N Engl J Med 2016; 375(21): 2019-21.

[9] Cocklin SL, Schmitz JE. The role of Fc receptors in HIV infection and vaccine efficacy. Curr Opin HIV AIDS 2014; 9(3): 257-62.

[10] Forthal DN, Moog C. Fc receptor-mediated antiviral antibodies. Curr Opin HIV AIDS 2009; 4(5): 388-93.

[11] Bruel T, Guivel-Benhassine F, Amraoui S, et al. Elimination of HIV-1-infected cells by broadly neutralizing antibodies. Nat Commun 2016; 7: 10844.

[12] Mascola JR, Haynes BF. HIV-1 neutralizing antibodies: understanding nature's pathways. Immunol Rev 2013; 254(1): 22544.

[13] Chung AW, Rollman E, Center RJ, Kent SJ, Stratov I. Rapid degranulation of NK cells following activation by HIV-specific antibodies. J Immunol 2009; 182(2): 1202-10.

[14] Clement MV, Haddad P, Soulie A, Guillet J, Sasportes M. Involvement of granzyme B and perforin gene expression in the lytic potential of human natural killer cells. Nouv Rev Fr Hematol 1990; 32(5): 349-52.

[15] Nagarajan S, Chesla S, Cobern L, et al. Ligand binding and phagocytosis by CD16 (Fc gamma receptor III) isoforms. Phagocytic signaling by associated zeta and gamma subunits in Chinese hamster ovary cells. J Biol Chem 1995; 270(43): 2576270.

[16] Scully E, Alter G. NK Cells in HIV disease. Curr HIV/AIDS Rep. 2016.

[17] Takasugi J, Koide Y, Takasugi M. Reconstitution of natural cellmediated cytotoxicity with specific antibodies. Eur J Immunol 1977; 7(12): 887-92.

[18] Ackerman ME, Dugast AS, McAndrew EG, et al. Enhanced phagocytic activity of HIV-specific antibodies correlates with natural production of immunoglobulins with skewed affinity for FcgammaR2a and FcgammaR2b. J Virol 2013; 87(10): 5468-76.

[19] French MA, Tanaskovic S, Law MG, et al. Vaccine-induced IgG2 anti-HIV p24 is associated with control of HIV in patients with a 'high-affinity' FcgammaRIIa genotype. AIDS 2010; 24(13): 198390.

[20] Holl V, Hemmerter S, Burrer R, et al. Involvement of Fc gamma RI (CD64) in the mechanism of HIV-1 inhibition by polyclonal IgG purified from infected patients in cultured monocyte-derived macrophages. J Immunol 2004; 173(10): 6274-83.

[21] Lee WS, Richard J, Lichtfuss M, et al. Antibody-dependent cellular cytotoxicity against reactivated HIV-1-infected cells. J Virol 2015; 90(4): 2021-30.

[22] Peng X, Li SS, Gilbert PB, Geraghty DE, Katze MG. FCGR2C polymorphisms associated with HIV-1 vaccine protection are linked to altered gene expression of $\mathrm{Fc}$-gamma receptors in human B cells. PLoS One 2016; 11(3): e0152425.

[23] Tanneau F, McChesney M, Lopez O, et al. Primary cytotoxicity against the envelope glycoprotein of human immunodeficiency virus-1: evidence for antibody-dependent cellular cytotoxicity in vivo. J Infect Dis 1990; 162(4): 837-43.

[24] Metzger H. Transmembrane signaling: the joy of aggregation. J Immunol 1992; 149(5): 1477-87.

[25] Yang J, Reth M. Receptor dissociation and B-cell activation. Curr Topics Microbiol Immunol 2016; 393: 27-43.

[26] Hogarth PM, Pietersz GA. Targeting receptors for antibodies (Fc receptors) in the treatment of human disease. Nat Rev Drug Discovery 2012; 11:311-31.

[27] Bruhns P, Iannascoli B, England P, et al. Specificity and affinity of human Fcgamma receptors and their polymorphic variants for human IgG subclasses. Blood 2009; 113(16): 3716-25. 
[28] Powell MS, Barton PA, Emmanouilidis D, et al. Biochemical analysis and crystallisation of Fc gamma RIIa, the low affinity receptor for IgG. Immunol Lett 1999; 68(1): 17-23.

[29] Chenoweth AM, Trist HM, Tan PS, Wines BD, Hogarth PM. The high-affinity receptor for IgG, FcgammaRI, of humans and nonhuman primates. Immunol Rev 2015; 268(1): 175-91.

[30] Rogers KA, Scinicariello F, Attanasio R. IgG Fc receptor III homologues in nonhuman primate species: genetic characterization and ligand interactions. J Immunol 2006; 177(6): 3848-56.

[31] Warncke M, Calzascia T, Coulot M, et al. Different adaptations of IgG effector function in human and nonhuman primates and implications for therapeutic antibody treatment. J Immunol 2012; 188(9): 4405-11.

[32] Trist HM, Tan PS, Wines BD, et al. Polymorphisms and interspecies differences of the activating and inhibitory FcgammaRII of Macaca nemestrina influence the binding of human IgG subclasses. J Immunol 2014; 192(2): 792-803.

[33] Chan YN, Boesch AW, Osei-Owusu NY, et al. IgG binding characteristics of rhesus macaque FcgammaR. J Immunol 2016; 197(7): 2936-47.

[34] Hessell AJ, Hangartner L, Hunter M, et al. Fc receptor but not complement binding is important in antibody protection against HIV. Nature 2007; 449(7158): 101-4.

[35] Hessell AJ, Poignard P, Hunter M, et al. Effective, low-titer antibody protection against low-dose repeated mucosal SHIV challenge in macaques. Nat Med 2009; 15(8): 951-4.

[36] Barouch DH, Stephenson KE, Borducchi EN, et al. Protective efficacy of a global HIV-1 mosaic vaccine against heterologous SHIV challenges in rhesus monkeys. Cell 2013; 155(3): 531-9.

[37] Gomez-Roman VR, Patterson LJ, Venzon D, et al. Vaccine-elicited antibodies mediate antibody-dependent cellular cytotoxicity correlated with significantly reduced acute viremia in rhesus macaques challenged with SIVmac251. J Immunol 2005; 174(4): 2185-9.

[38] Guan Y, Pazgier M, Sajadi MM, et al. Diverse specificity and effector function among human antibodies to HIV-1 envelope glycoprotein epitopes exposed by CD4 binding. Proc Natl Acad Sci USA 2013; 110(1): E69-78.

[39] Decker JM, Bibollet-Ruche F, Wei X, et al. Antigenic conservation and immunogenicity of the HIV coreceptor binding site. J Exp Med 2005; 201(9): 1407-19.

[40] Fauci AS, Marovich MA, Dieffenbach CW, Hunter E, Buchbinder SP. Immunology. Immune activation with HIV vaccines. Sci 2014; 344(6179): 49-51

[41] Fouts TR, Bagley K, Prado IJ, et al. Balance of cellular and humoral immunity determines the level of protection by HIV vaccines in rhesus macaque models of HIV infection. Proc Natl Acad Sci USA 2015; 112(9): E992-9.

[42] Gordon SN, Liyanage NP, Doster MN, et al. Boosting of ALVACSIV Vaccine-Primed Macaques with the CD4-SIVgp120 Fusion Protein Elicits Antibodies to V2 Associated with a Decreased Risk of SIVmac251 Acquisition. J Immunol 2016; 197: 2726-37.

[43] Horwitz JA, Halper-Stromberg A, Mouquet H, et al. HIV-1 suppression and durable control by combining single broadly neutralizing antibodies and antiretroviral drugs in humanized mice. Proc Natl Acad Sci USA 2013; 110(41): 16538-43.

[44] Bournazos S, Klein F, Pietzsch J, et al. Broadly neutralizing antiHIV-1 antibodies require Fc effector functions for in vivo activity. Cell 2014; 158(6): 1243-53

[45] Halper-Stromberg A, Lu CL, Klein F, et al. Broadly neutralizing antibodies and viral inducers decrease rebound from HIV-1 latent reservoirs in humanized mice. Cell 2014; 158(5): 989-99.

[46] Haynes BF, Gilbert PB, McElrath MJ, et al. Immune-correlates analysis of an HIV-1 vaccine efficacy trial. N Engl J Med 2012; 366(14): 1275-86.

[47] Rerks-Ngarm S, Pitisuttithum P, Nitayaphan S, et al. Vaccination with ALVAC and AIDSVAX to prevent HIV-1 infection in Thailand. N Engl J Med 2009; 361(23): 2209-20.

[48] Yates NL, Liao HX, Fong Y, et al. Vaccine-induced Env V1-V2 IgG3 correlates with lower HIV-1 infection risk and declines soon after vaccination. Sci Transl Med 2014; 6(228): 228 ra39.

[49] Zolla-Pazner S, deCamp A, Gilbert PB, et al. Vaccine-induced IgG antibodies to V1V2 regions of multiple HIV-1 subtypes correlate with decreased risk of HIV-1 infection. PLoS One 2014; 9(2): e87572.
[50] Chung AW, Ghebremichael M, Robinson H, et al. Polyfunctional Fc-effector profiles mediated by IgG subclass selection distinguish RV144 and VAX003 vaccines. Sci Transl Med 2014; 6(228): 228 ra38.

[51] Bonsignori M, Hwang KK, Chen X, et al. Analysis of a clonal lineage of HIV-1 envelope V2/V3 conformational epitope-specific broadly neutralizing antibodies and their inferred unmutated common ancestors. J Virol 2011; 85(19): 9998-10009.

[52] Liao HX, Bonsignori M, Alam SM, et al. Vaccine induction of antibodies against a structurally heterogeneous site of immune pressure within HIV-1 envelope protein variable regions 1 and 2 . Immunity 2013; 38(1): 176-86.

[53] Zolla-Pazner S, deCamp AC, Cardozo T, et al. Analysis of V2 antibody responses induced in vaccinees in the ALVAC/ AIDSVAX HIV-1 vaccine efficacy trial. PLoS One 2013; 8(1): e53629.

[54] Rolland M, Edlefsen PT, Larsen BB, et al. Increased HIV-1 vaccine efficacy against viruses with genetic signatures in Env V2. Nature 2012; 490(7420): 417-20.

[55] Alpert MD, Harvey JD, Lauer WA, et al. ADCC develops over time during persistent infection with live-attenuated SIV and is associated with complete protection against SIV(mac)251 challenge. PLoS Pathog 2012; 8(8): e1002890.

[56] Bonsignori M, Pollara J, Moody MA, et al. Antibody-dependent cellular cytotoxicity-mediating antibodies from an HIV-1 vaccine efficacy trial target multiple epitopes and preferentially use the VH1 gene family. J Virol 2012; 86(21): 11521-32.

[57] Chung AW, Navis M, Isitman G, et al. Activation of NK cells by ADCC antibodies and HIV disease progression. J Acquir Immune Defic Syndr 2011; 58(2): 127-31.

[58] Corti D, Lanzavecchia A. Broadly neutralizing antiviral antibodies. Annu Rev Immunol 2013; 31: 705-42.

[59] Zolla-Pazner S, Powell R, Yahyaei S, et al. Rationally-designed vaccines targeting the V2 region of HIV-1 gp120 induce a focused, cross clade-reactive, biologically functional antibody response. J Virol 2016; 90(24): 10993-1006.

[60] Forthal DN, Gilbert PB, Landucci G, Phan T. Recombinant gp120 vaccine-induced antibodies inhibit clinical strains of HIV-1 in the presence of $\mathrm{Fc}$ receptor-bearing effector cells and correlate inversely with HIV infection rate. J Immunol 2007; 178(10): 6596603.

[61] Ackerman ME, Mikhailova A, Brown EP, et al. Polyfunctional HIV-specific antibody responses are associated with spontaneous HIV control. PLoS Pathog 2016; 12(1): e1005315.

[62] Brown J, Excler JL, Kim JH. New prospects for a preventive HIV1 vaccine. J Virus Erad 2015; 1(2): 78-88.

[63] Wren L, Stratov I, Kent S, Parsons M. Obstacles to ideal anti-HIV antibody-dependent cellular cytotoxicity responses. Vaccine 2013; 31(47): 5506-17.

[64] Caskey M, Klein F, Nussenzweig MC. Broadly neutralizing antibodies for HIV-1 prevention or immunotherapy. N Engl J Med $0(0)$ : null.

[65] Schoofs T, Klein F, Braunschweig M, et al. HIV-1 therapy with monoclonal antibody 3BNC117 elicits host immune responses against HIV-1. Sci 2016; 352(6288): 997-1001.

[66] DiLillo DJ, Ravetch JV. Differential Fc-receptor engagement drives an anti-tumor vaccinal effect. Cell 2015; 161(5): 1035-45.

[67] Lu CL, Murakowski DK, Bournazos S, et al. Enhanced clearance of HIV-1-infected cells by broadly neutralizing antibodies against HIV-1 in vivo. Science 2016; 352(6288): 1001-4.

[68] Forthal DN, Landucci G, Daar ES. Antibody from patients with acute human immunodeficiency virus (HIV) infection inhibits primary strains of HIV type 1 in the presence of natural-killer effector cells. J Virol 2001; 75(15): 6953-61.

[69] Baum LL, Cassutt KJ, Knigge K, et al. HIV-1 gp120-specific antibody-dependent cell-mediated cytotoxicity correlates with rate of disease progression. J Immunol 1996; 157(5): 2168-73.

[70] Holl V, Peressin M, Moog C. Antibody-mediated fcgamma receptor-based mechanisms of HIV inhibition: Recent findings and new vaccination strategies. Viruses 2009; 1(3): 1265-94.

[71] Madhavi V, Kent SJ, Stratov I. HIV-specific antibody-dependent cellular cytotoxicity: a novel vaccine modality. Expert Rev Clin Immunol 2012; 8(8): 767-74.

[72] Lambotte O, Pollara J, Boufassa F, et al. High antibody-dependent cellular cytotoxicity responses are correlated with strong CD8 T 
cell viral suppressive activity but not with B57 status in HIV-1 elite controllers. PLoS One 2013; 8(9): e74855.

[73] Huang Y, Ferrari G, Alter G, et al. Diversity of antiviral IgG effector activities observed in HIV-infected and vaccinated subjects. J Immunol 2016; 197(12): 4603-12.

[74] Jeffries TL, Jr., Sacha CR, Pollara J, et al. The function and affinity maturation of HIV-1 gp120-specific monoclonal antibodies derived from colostral B cells. Mucosal Immunol 2016; 9(2): 414-27.

[75] Milligan C, Richardson BA, John-Stewart G, Nduati R, Overbaugh J. Passively acquired antibody-dependent cellular cytotoxicity (ADCC) activity in HIV-infected infants is associated with reduced mortality. Cell Host Microbe 2015; 17(4): 500-6.

[76] Mabuka J, Nduati R, Odem-Davis K, Peterson D, Overbaugh J. HIV-specific antibodies capable of ADCC are common in breastmilk and are associated with reduced risk of transmission in women with high viral loads. PLoS Pathog 2012; 8(6): e1002739.

[77] Dugast AS, Tonelli A, Berger CT, et al. Decreased Fc receptor expression on innate immune cells is associated with impaired antibody-mediated cellular phagocytic activity in chronically HIV1 infected individuals. Virology 2011;415(2): 160-7.

[78] Barnes N, Gavin AL, Tan PS, et al. FcgammaRI-deficient mice show multiple alterations to inflammatory and immune responses. Immunity 2002; 16(3): 379-89.

[79] Abboud N, Chow SK, Saylor C, et al. A requirement for FcgammaR in antibody-mediated bacterial toxin neutralization. J Exp Med 2010; 207(11): 2395-405.

[80] Holl V, Peressin M, Decoville T, et al. Nonneutralizing antibodies are able to inhibit human immunodeficiency virus type 1 replication in macrophages and immature dendritic cells. J Virol 2006; 80(12): 6177-81.

[81] Perez LG, Costa MR, Todd CA, Haynes BF, Montefiori DC. Utilization of immunoglobulin $\mathrm{G} F \mathrm{Fc}$ receptors by human immunodeficiency virus type 1: a specific role for antibodies against the membrane-proximal external region of gp41. J Virol 2009; 83(15): 7397-410

[82] Peressin M, Holl V, Schmidt S, et al. HIV-1 replication in Langerhans and interstitial dendritic cells is inhibited by neutralizing and Fc-mediated inhibitory antibodies. J Virol 2011; 85(2): 1077-85

[83] Nguyen DC, Scinicariello F, Attanasio R. Characterization and allelic polymorphisms of rhesus macaque (Macaca mulatta) IgG Fc receptor genes. Immunogenet 2011; 63(6): 351-62.

[84] Hulett MD, Hogarth PM. Molecular basis of Fc receptor function. Adv Immunol 1994; 57: 1-127.

[85] Ravetch JV. A full complement of receptors in immune complex diseases. J Clin Invest 2002; 110(12): 1759-61.

[86] Cady CT, Powell MS, Harbeck RJ, et al. IgG antibodies produced during subcutaneous allergen immunotherapy mediate inhibition of basophil activation via a mechanism involving both FcgammaRIIA and FcgammaRIIB. Immunol Lett 2010; 130(1-2): 57-65.

[87] Radstake TR, Petit E, Pierlot C, et al. Role of Fcgamma receptors IIA, IIIA, and IIIB in susceptibility to rheumatoid arthritis. J Rheumatol 2003; 30(5): 926-33.

[88] Mullazehi M, Mathsson L, Lampa J, Ronnelid J. Surface-bound anti-type II collagen-containing immune complexes induce production of tumor necrosis factor alpha, interleukin-1beta, and interleukin-8 from peripheral blood monocytes via Fc gamma receptor IIA: a potential pathophysiologic mechanism for humoral anti-type II collagen immunity in arthritis. Arthritis Rheum 2006; 54(6): 1759-71.

[89] Tate BJ, Witort E, McKenzie IF, Hogarth PM. Expression of the high responder/non-responder human Fc gamma RII. Analysis by PCR and transfection into FcR-COS cells. Immunol Cell Biol 1992; 70 ( Pt 2): 79-87.

[90] Brown EE, Edberg JC, Kimberly RP. Fc receptor genes and the systemic lupus erythematosus diathesis. Autoimmunity 2007; 40(8): 567-81.

[91] Floto RA, Clatworthy MR, Heilbronn KR, et al. Loss of function of a lupus-associated FcgammaRIIb polymorphism through exclusion from lipid rafts. Nat Med 2005; 11(10): 1056-8.

[92] Karassa FB, Trikalinos TA, Ioannidis JP. The role of FcgammaRIIA and IIIA polymorphisms in autoimmune diseases. Biomed Pharmacother 2004; 58(5): 286-91.

[93] Taylor SM, Reilly MP, Schreiber AD, et al. Thrombosis and shock induced by activating antiplatelet antibodies in human Fcgamma-
RIIA transgenic mice: the interplay among antibody, spleen, and Fc receptor. Blood 2000; 96(13): 4254-60.

[94] Asano K, Matsushita T, Umeno J, et al. A genome-wide association study identifies three new susceptibility loci for ulcerative colitis in the Japanese population. Nat Genet 2009; 41(12): 1325-9.

[95] Raychaudhuri S, Thomson BP, Remmers EF, et al. Genetic variants at $\mathrm{CD} 28, \mathrm{PRDM} 1$ and $\mathrm{CD} 2 / \mathrm{CD} 58$ are associated with rheumatoid arthritis risk. Nat Genet 2009; 41(12): 1313-8.

[96] Pawlik A, Ostanek L, Brzosko I, et al. FC gamma RIIa polymorphism in patients with rheumatoid arthritis. Clin Exp Rheumatol 2002; 20(6): 841-4.

[97] Ouma C, Keller CC, Opondo DA, et al. Association of FCgamma receptor IIA (CD32) polymorphism with malarial anemia and highdensity parasitemia in infants and young children. Am J Trop Med Hyg 2006; 74(4): 573-7.

[98] Nicu EA, Van der Velden U, Everts V, et al. Hyper-reactive PMNs in FcgammaRIIa $131 \mathrm{H} / \mathrm{H}$ genotype periodontitis patients. J Clin Periodontol 2007; 34(11): 938-45

[99] Yee AM, Phan HM, Zuniga R, Salmon JE, Musher DM. Association between FcgammaRIIa-R131 allotype and bacteremic pneumococcal pneumonia. Clin Infect Dis 2000; 30(1): 25-8.

[100] Forthal DN, Landucci G, Bream J, et al. FcgammaRIIa genotype predicts progression of HIV infection. J Immunol 2007; 179(11) 7916-23.

[101] Forthal DN, Gabriel EE, Wang A, Landucci G, Phan TB. Association of Fcgamma receptor IIIa genotype with the rate of HIV infection after gp120 vaccination. Blood 2012; 120(14): 283642.

[102] Ana-Sosa-Batiz F, Johnston AP, Liu H, et al. HIV-specific antibody-dependent phagocytosis matures during HIV infection. Immunol Cell Biol 2014; 92(8): 679-87.

[103] Sips M, Krykbaeva M, Diefenbach TJ, et al. Fc receptor-mediated phagocytosis in tissues as a potent mechanism for preventive and therapeutic HIV vaccine strategies. Mucosal Immunol 2016; 9(6): 1584-95.

[104] Daeron M, Latour S, Malbec O, et al. The same tyrosine-based inhibition motif, in the intracytoplasmic domain of Fc gamma RIIB, regulates negatively BCR-, TCR-, and FcR-dependent cell activation. Immunity 1995; 3(5): 635-46.

[105] Ono M, Bolland S, Tempst P, Ravetch JV. Role of the inositol phosphatase SHIP in negative regulation of the immune system by the receptor Fc(gamma)RIIB. Nature 1996; 383(6597): 263-6.

[106] Getahun A, Cambier JC. Of ITIMs, ITAMs, and ITAMis: revisiting immunoglobulin Fc receptor signaling. Immunol Rev 2015; 268(1) 66-73.

[107] Su K, Yang H, Li X, et al. Expression profile of FcgammaRIIb on leukocytes and its dysregulation in systemic lupus erythematosus. J Immunol 2007; 178(5): 3272-80.

[108] Isakov N. ITIMs and ITAMs. The Yin and Yang of antigen and Fc receptor-linked signaling machinery. Immunol Res 1997; 16(1): 85-100.

[109] van der Heijden J, Breunis WB, Geissler J, et al. Phenotypic Variation in IgG Receptors by Nonclassical FCGR2C Alleles. J Immunol 2011; 188(3): 1318-24.

[110] Li SS, Gilbert PB, Tomaras GD, et al. FCGR2C polymorphisms associate with HIV-1 vaccine protection in RV144 trial. J Clin Invest 2014; 124(9): 3879-90.

[111] Lee J, Zhang T, Hwang I, et al. Epigenetic modification and antibody-dependent expansion of memory-like NK cells in human cytomegalovirus-infected individuals. Immunity 2015; 42(3): 43142 .

[112] Zhou J, Amran FS, Kramski M, et al. An NK cell population lacking FcRgamma is expanded in chronically infected HIV patients. J Immunol. 2015; 194(10): 4688-97.

[113] Wagner JA, Fehniger TA. Human adaptive natural killer cells: Beyond NKG2C. Trends in Immunology 2016; 37(6): 351-3.

[114] Musolino A, Naldi N, Bortesi B, et al. Immunoglobulin G fragment $\mathrm{C}$ receptor polymorphisms and clinical efficacy of trastuzumabbased therapy in patients with HER-2/neu-positive metastatic breast cancer. J Clin Oncol 2008; 26(11): 1789-96.

[115] Weng WK, Levy R. Two immunoglobulin G fragment C receptor polymorphisms independently predict response to rituximab in patients with follicular lymphoma. J Clin Oncol 2003; 21(21): 3940-7. 
[116] Poonia B, Kijak GH, Pauza CD. High affinity allele for the gene of FCGR3A is risk factor for HIV infection and progression. PLoS One 2010; 5(12): e15562.

[117] Weis JF, McClelland RS, Jaoko W, et al. Short communication: Fc gamma receptors IIa and IIIa genetic polymorphisms do not predict HIV-1 disease progression in Kenyan women. AIDS Res Hum Retroviruses 2015; 31(3): 288-92.

[118] Pandey JP, Namboodiri AM, Bu S, et al. Immunoglobulin genes and the acquisition of HIV infection in a randomized trial of recombinant adenovirus HIV vaccine. Virology 2013; 441(1): 70-4.

[119] Lassauniere R, Musekiwa A, Gray GE, Kuhn L, Tiemessen CT. Perinatal HIV-1 transmission: Fc gamma receptor variability associates with maternal infectiousness and infant susceptibility. Retrovirology 2016; 13(1): 40.

[120] Ferrara C, Grau S, Jager C, et al. Unique carbohydratecarbohydrate interactions are required for high affinity binding between FcgammaRIII and antibodies lacking core fucose. Proc Natl Acad Sci USA 2011; 108(31): 12669-74.

[121] Ferrara C, Stuart F, Sondermann P, Brunker P, Umana P. The carbohydrate at FcgammaRIIIa Asn-162. An element required for high affinity binding to non-fucosylated IgG glycoforms. J Biol Chem 2006; 281(8): 5032-6

[122] Shinkawa T, Nakamura K, Yamane N, et al. The absence of fucose but not the presence of galactose or bisecting $\mathrm{N}$-acetylglucosamine of human IgG1 complex-type oligosaccharides shows the critical role of enhancing antibody-dependent cellular cytotoxicity. J Biol Chem 2003; 278(5): 3466-73.

[123] Chung AW, Crispin M, Pritchard L, et al. Identification of antibody glycosylation structures that predict monoclonal antibody Fceffector function. AIDS 2014; 28(17): 2523-30.

[124] Herter S, Herting F, Mundigl O, et al. Preclinical activity of the type II CD20 antibody GA101 (obinutuzumab) compared with rituximab and ofatumumab in vitro and in xenograft models. Mol Cancer Ther 2013; 12(10): 2031-42.

[125] Iida S, Misaka H, Inoue M, et al. Nonfucosylated therapeutic IgG1 antibody can evade the inhibitory effect of serum immunoglobulin $\mathrm{G}$ on antibody-dependent cellular cytotoxicity through its high binding to FcgammaRIIIa. Clin Cancer Res 2006; 12(9): 2879-87.

[126] Perez-Callejo D, Gonzalez-Rincon J, Sanchez A, Provencio M, Sanchez-Beato M. Action and resistance of monoclonal CD20 antibodies therapy in B-cell Non-Hodgkin Lymphomas. Cancer Treat Rev 2015; 41(8): 680-9.

[127] Moldt B, Shibata-Koyama M, Rakasz EG, et al. A nonfucosylated variant of the anti-HIV-1 monoclonal antibody b12 has enhanced FcgammaRIIIa-mediated antiviral activity in vitro but does not improve protection against mucosal SHIV challenge in macaques. J Virol 2012; 86(11): 6189-96.

[128] Derer S, Glorius P, Schlaeth M, et al. Increasing FcgammaRIIa affinity of an FcgammaRIII-optimized anti-EGFR antibody restores neutrophil-mediated cytotoxicity. MAbs 2014; 6(2): 409-21.

[129] Gunn BM, Schneider JR, Shansab M, et al. Enhanced binding of antibodies generated during chronic HIV infection to mucus component MUC16. Mucosal Immunol 2016; 9(6): 1549-58.

[130] Peterlin BM, Trono D. Hide, shield and strike back: how HIVinfected cells avoid immune eradication. Nat Rev Immunol 2003; 3(2): 97-107.

[131] Kirchhoff F. Immune evasion and counteraction of restriction factors by HIV-1 and other primate lentiviruses. Cell Host Microbe 2010; 8(1): 55-67.

[132] Richard J, Veillette M, Ding S, et al. Small CD4 mimetics prevent HIV-1 uninfected bystander CD4 + T cell killing mediated by antibody-dependent cell-mediated cytotoxicity. EBioMedicine 2016; 3: 122-34.

[133] Robinson JE, Elliott DH, Martin EA, Micken K, Rosenberg ES. High frequencies of antibody responses to CD4 induced epitopes in HIV infected patients started on HAART during acute infection. Human Antibodies 2005; 14(3-4): 115-21.

[134] von Bredow B, Arias JF, Heyer LN, et al. Comparison of Antibody-Dependent Cell-Mediated Cytotoxicity and Virus Neutralization by HIV-1 Env-Specific Monoclonal Antibodies. J Virol 2016; 90(13): 6127-39.

[135] Mengistu M, Ray K, Lewis GK, DeVico AL. Antigenic properties of the human immunodeficiency virus envelope glycoprotein gp120 on virions bound to target cells. PLoS Pathog 2015; 11(3): e1004772.
[136] Tolbert WD, Gohain N, Veillette M, et al. Paring down HIV env: design and crystal structure of a stabilized inner domain of HIV-1 gp120 displaying a major ADCC target of the A32 region. Structure 2016; 24(5): 697-709.

[137] Arien KK, Baleux F, Desjardins D, et al. CD4-mimetic sulfopeptide conjugates display sub-nanomolar anti-HIV-1 activity and protect macaques against a SHIV162P3 vaginal challenge. Scientific Reports 2016; 6: 34829 .

[138] Richard J, Pacheco B, Gohain N, et al. Co-receptor Binding Site Antibodies Enable CD4-Mimetics to Expose Conserved Anticluster A ADCC Epitopes on HIV-1 Envelope Glycoproteins. EBioMedicine 2016; 12: 208-18.

[139] Madani N, Princiotto AM, Easterhoff D, et al. Antibodies elicited by multiple envelope glycoprotein immunogens in primates neutralize primary human immunodeficiency viruses (HIV-1) sensitized by CD4-mimetic compounds. J Virol 2016; 90(10): 5031-46.

[140] Mi Z, Ding J, Zhang Q, et al. A small molecule compound IMBLA inhibits HIV-1 infection by preventing viral Vpu from antagonizing the host restriction factor BST-2. Sci Rep 2015; 5: 18499.

[141] Glanville J, Zhai W, Berka J, et al. Precise determination of the diversity of a combinatorial antibody library gives insight into the human immunoglobulin repertoire. Proc Natl Acad Sci USA 2009; 106(48): 20216-21.

[142] Acharya P, Tolbert WD, Gohain N, et al. Structural definition of an antibody-dependent cellular cytotoxicity response implicated in reduced risk for HIV-1 infection. J Virol 2014; 88(21): 12895-906.

[143] Pollara J, Bonsignori M, Moody MA, et al. HIV-1 vaccine-induced $\mathrm{C} 1$ and V2 Env-specific antibodies synergize for increased antiviral activities. J Virol 2014; 88(14): 7715-26.

[144] Munro JB, Mothes W. Structure and Dynamics of the Native HIV1 Env Trimer. J Virol 2015; 89(11): 5752-5.

[145] Wang H, Cohen AA, Galimidi RP, et al. Cryo-EM structure of a CD4-bound open HIV-1 envelope trimer reveals structural rearrangements of the gp120 V1V2 loop. Proc Natl Acad Sci USA 2016; 113(46): E7151-E8.

[146] Sanders RW, Derking R, Cupo A, et al. A next-generation cleaved, soluble HIV-1 Env trimer, BG505 SOSIP.664 gp140, expresses multiple epitopes for broadly neutralizing but not non-neutralizing antibodies. PLoS Pathog 2013; 9(9): e1003618.

[147] Memarnejadian A, Meilleur CE, Mazzuca DM, Welch ID, Haeryfar SM. Quantification of alloantibody-mediated cytotoxicity in vivo. Transplantation 2016; 100(5): 1041-51.

[148] Valiathan R, Lewis JE, Melillo AB, et al. Evaluation of a flow cytometry-based assay for natural killer cell activity in clinical settings. Scand J Immunol 2012; 75(4): 455-62.

[149] Zaritskaya L, Shurin MR, Sayers TJ, Malyguine AM. New flow cytometric assays for monitoring cell-mediated cytotoxicity. Expert Rev Vaccines 2010; 9(6): 601-16.

[150] Gomez-Roman VR, Florese RH, Patterson LJ, et al. A simplified method for the rapid fluorometric assessment of antibodydependent cell-mediated cytotoxicity. J Immunol Methods 2006; 308(1-2): 53-67.

[151] Orlandi C, Flinko R, Lewis GK. A new cell line for high throughput HIV-specific antibody-dependent cellular cytotoxicity (ADCC) and cell-to-cell virus transmission studies. J Immunol Methods 2016; 433: 51-8.

[152] Forthal DN, Landucci G. In vitro reduction of virus infectivity by antibody-dependent cell-mediated immunity. J Immunol Methods 1998; 220(1-2): 129-38.

[153] Vanderven H. Research paper: What lies beneath: Antibody dependent natural killer cell activation by antibodies to internal influenza virus proteins. EBioMedicine 2016; 8: 277-290.

[154] Pollara J, Hart L, Brewer F, et al. High-throughput quantitative analysis of HIV-1 and SIV-specific ADCC-mediating antibody responses. Cytometry A 2011; 79(8): 603-12.

[155] Konstantinus IN, Gamieldien H, Mkhize NN, Kriek JM, Passmore JA. Comparing high-throughput methods to measure NK cellmediated antibody dependent cellular cytotoxicity during HIVinfection. J Immunol Methods 2016; 434: 46-52.

[156] Blomberg K, Granberg C, Hemmila I, Lovgren T. Europiumlabelled target cells in an assay of natural killer cell activity. I. A novel non-radioactive method based on time-resolved fluorescence. J Immunol Methods 1986; 86(2): 225-9. 
[157] Gooneratne SL, Richard J, Lee WS, et al. Slaying the Trojan horse: natural killer cells exhibit robust anti-HIV-1 antibody-dependent activation and cytolysis against allogeneic T cells. J Virol 2015; 89(1): 97-109.

[158] Trkola A, Matthews J, Gordon C, Ketas T, Moore JP. A cell linebased neutralization assay for primary human immunodeficiency virus type 1 isolates that use either the CCR5 or the CXCR4 coreceptor. J Virol 1999; 73(11): 8966-74.

[159] Kramski M, Schorcht A, Johnston AP, et al. Role of monocytes in mediating HIV-specific antibody-dependent cellular cytotoxicity. J Immunol Methods 2012; 384(1-2): 51-61.

[160] Chung AW, Isitman G, Navis M, et al. Immune escape from HIVspecific antibody-dependent cellular cytotoxicity (ADCC) pressure. Proc Natl Acad Sci USA 2011; 108(18): 7505-10.

[161] Kantakamalakul W, Pattanapanyasat K, Jongrakthaitae S, et al. A novel EGFP-CEM-NKr flow cytometric method for measuring antibody dependent cell mediated-cytotoxicity (ADCC) activity in HIV-1 infected individuals. J Immunol Methods 2006; 315(1-2): 110 .

[162] Alpert MD, Heyer LN, Williams DE, et al. A novel assay for antibody-dependent cell-mediated cytotoxicity against HIV-1- or SIV-infected cells reveals incomplete overlap with antibodies measured by neutralization and binding assays. J Virol 2012; 86(22): 12039-52.

[163] ADCC develops over time during persistent infection withAlvarez RA, Hamlin RE, Monroe A, et al. HIV-1 Vpu antagonism of tetherin inhibits antibody-dependent cellular cytotoxic responses by natural killer cells. J Virol 2014; 88(11): 6031-46.

[164] Tay MZ, Liu P, Williams LD, et al. Antibody-mediated internalization of infectious HIV-1 virions differs among antibody isotypes and subclasses. PLoS Pathogens 2016; 12(8): e1005817.

[165] Lux A, Yu X, Scanlan CN, Nimmerjahn F. Impact of immune complex size and glycosylation on $\operatorname{IgG}$ binding to human FcgammaRs. J Immunol 2013; 190(8): 4315-23.

[166] Moldt B, Schultz N, Dunlop DC, et al. A panel of IgG1 b12 variants with selectively diminished or enhanced affinity for Fcgamma receptors to define the role of effector functions in protection against HIV. J Virol 2011; 85(20): 10572-81.

[167] Boesch AW, Brown EP, Cheng HD, et al. Highly parallel characterization of IgG Fc binding interactions. MAbs 2014; 6(4): 915-27.

[168] Wines BD, Vanderven HA, Esparon SE, et al. Dimeric FcgammaR Ectodomains as Probes of the Fc Receptor Function of AntiInfluenza Virus IgG. J Immunol 2016; 197(4): 1507-16. 